$14^{\text {th }}$ Conf. Agric. Develop. Res., Fac. of Agric.,

Ain Shams Univ., March, 2019., Cairo, Egypt

Special Issue, 27(1), 313 - 322, 2019

Website: http://strategy-plan.asu.edu.eg/AUJASCl/

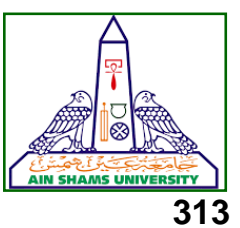

\title{
EFFECT OF PROPIOTIC ON RUMINANT PERFORMANCE
}

\author{
Elbarbary', A.F., Gado ${ }^{1}$, H.M. and Khattab ${ }^{1}$ H.M.
}

Animal Production Dept., Fac. of Agric., Ain Shams Univ., P.O. Box 68 Hadyek Shoubra 11241, Cairo, Egypt

*Corresponding author: abdelrahman.fa@gmail.com

Received 14 October, 2018, Accepted 24 October, 2018

\begin{abstract}
Two hundred multiparous Holstein dairy cows post-partum were randomly assigned into two groups. The first group (control, $n=100$ ) was fed total mixed ration (TMR) without a supplement of liquid probiotic enzymes. The second group (treatment, $n=100$ ) was fed TMR supplemented with a commercial probiotic (ZAD) prepared by Bactizad company, Cairo, Egypt. at the rate of 10 $\mathrm{ml} /$ head/day. According to the guide of the manufacture for 12 weeks ZAD was added and mixed to the TMR at the time of feeding once per day. Each group was placed in a shaded pen equipped with free stalls.
\end{abstract}

\section{Results obtained showed that}

Milk yield increased significantly from 39.57 $\mathrm{kg} /$ day for control group up to $41.73 \mathrm{~kg} /$ day for treated with ZAD group.

Fat and protein milk percentage tended to be improved due to treated with ZAD but the difference was not significant.

Lactose percentage was affected positively and significantly by treated of ZAD, lactose percentage was 4.79 for control group and 4.83 for ZAD group.

Serum total protein increased significantly from $11.52(\mathrm{~g} / \mathrm{dl})$ for control group up to $11.85(\mathrm{~g} / \mathrm{dl})$ for treated ZAD group. Albumin was significantly higher in control group.

Results indicated that blood urea concentration in treated group being $34.77(\mathrm{mg} / \mathrm{dl})$ and for the control group 33.91 (mg/dl), was significantly higher.

Alkaline phosphates increased significantly in treated group from $21.105 \mathrm{U} / \mathrm{l}$ for control group up to $26.92 \mathrm{U} / \mathrm{l}$ for treated group.
Cholesterol concentration was reduced significantly due to treatment from $240.98 \mathrm{mg} / \mathrm{dl}$ in control cows to $190.13 \mathrm{mg} / \mathrm{dl}$ in treated cows.

Triglycerides concentration declined significantly due to treatment of probiotic ZAD. In control cows triglycerides concentration was 27.871 $(\mathrm{mg} / \mathrm{dl})$ and treated cows was $20.9781(\mathrm{mg} / \mathrm{dl})$.

T3 concentration increased significantly as a response to treatment by probiotic ZAD. T3 concentration was $117.29 \mathrm{ng} / \mathrm{dl}$ in treated group and $62.38 \mathrm{mg} / \mathrm{dl}$ in control group.

Keywords: Probiotics, Ruminant, ZAD, production, blood parameters, performance.

\section{INTRODUCTION}

Parker (1974) was the first to coin "PROBIOTIC", he described it as "microorganism or substance that affect the intestinal microbial balance". Furthermore, probiotic was defined as "a live microbial feed supplement which improve the intestinal microbial balance beneficially The term probiotic has a contrast with the term antibiotic which means "against life" (Fuller 1989).

More recently, the US food and Drug Administration classified probiotic as GRAS (Generally Recognized As Safe) ingredient. To be used for improving the productive potentials of ruminants, pig and poultry. Moreover, Dutta et al (2009) reported the species to be employed in probiotic preparation as lactic acid bacteria like Lactobacillus acidophilus, Lactobacillus salivarius, Lactobacillus lactis, Lactobacillus plantarum, Lactobacillus bulgaricus, E. faecalis, Streptococcus thermophilus, Enterococcus faecium, Bifidobacterium species and Bacillus subtilis. 
Using enzymes as feed additives usually results increased feed intake, due to increased palatability of the diet because of sugars released by pre-ingestive fiber hydrolysis. On the other hand post-ingestive enzyme could increase digestion rate and/or extent of digestion (Beauchemin et al 1995, Feng et al 1996, Gado and Salem 2008, Krueger et al 2008) as a result hydrolytic activity in the rumen leading to reduced gut fill and consequently increased enhance feed intake (Adesogan et al 2005).

\section{Objective of study}

This work aimed to study the effect of probiotic treatments on multiparous Holstein dairy cows' milk production and composition and animal health.

\section{MATERIALS and METHODS}

The present study was performed from July 2014 to October 2014, at El-Amal farm, in Cairo. Egypt. Biochemical analyses, feed analyses and milk analyses were conducted in laboratories of Faculty of Agriculture, Ain Shams University, Cairo, Egypt.

\section{Animals}

At total of 200 multiparous Holstein dairy cows after calving were randomly assigned into two groups, the first group (control, $n=100$ ) and the second group (treatment, $n=100$ ), each group was divided into 5 subgroups with group feeding.

The control group was fed total mixed ration (TMR) without supplementing probiotic enzymes to the feeds. The treatment group was fed TMR supplemented with a commercial probiotic (ZAD) that is mixture of anaerobic bacteria and enzymes which is prepared by Bactizad company, Cairo, Egypt.

The cows in control and treatment groups were similar in milk production, days in milk and number of lactation seasons. Each group was placed in a shaded pen equipped with free stalls

\section{Treatment}

The rate of treatment was $10 \mathrm{ml} / \mathrm{cow} /$ day according to the guide of the manufacture recommendation. ZAD was added and mixed to the TMR at the time of feeding once per day. The experiment period was 12 weeks

\section{Feeding}

Cows were fed as a group open feed, with free access to water. Amount of TMR delivered was measured with electronic scales on mixer-feeder wagon. And amount of refused feed was measured to determine the daily feed intake (FI) and calculate the daily dry matter intake(DMI).

\section{Feed composition}

Each cow was fed $8.81 \mathrm{~kg} /$ day corn grain, 6.1 $\mathrm{kg} /$ day molasses, $0.28 \mathrm{~kg} /$ day tallow, $3.07 \mathrm{~kg} /$ day alfalfa meal, $6.58 \mathrm{~kg} /$ day soybean meal, 1,98 $\mathrm{kg} /$ day sun flower meal, and some minerals and additives.

TMR composition as dry matter, as-fed and dry matter percentage is shown in the following Tables (1 and 2).

Table 1. Daily intake and percentage of different TMR ingredient/each cow as dry matter ( $\mathrm{Kg} /$ day) and as fed $\mathrm{Kg} /$ day

\begin{tabular}{|c|c|c|c|}
\hline & kg/day & kg/day & $\%$ \\
\cline { 2 - 4 } & $\begin{array}{c}\text { (Dry } \\
\text { Feed Name }\end{array}$ & & (Dry \\
Matter) & (As-Fed) & Matter) \\
\hline Corn Grain, ground, dry & 7.76 & 8.81 & 28.64 \\
Molasses, Sugarcane & 4.54 & 6.1 & 16.73 \\
Tallow & 0.28 & 0.28 & 1.04 \\
Alfalfa Meal, 17\% CP & 2.77 & 3.07 & 10.21 \\
Soybean, Meal, solv. 44\% CP & 5.87 & 6.58 & 21.64 \\
Sunflower Meal, solvent & 1.83 & 1.98 & 6.75 \\
Calcium Carbonate & 0.17 & 0.17 & 0.62 \\
Calcium Phosphate (Di-) & 0.11 & 0.11 & 0.41 \\
Calcium Phosphate (Mono-) & 0.06 & 0.06 & 0.22 \\
Limestone & 0.06 & 0.06 & 0.22 \\
Magnesium Oxide & 0.06 & 0.06 & 0.22 \\
MonoSodium Phosphate (1 $\left.\mathrm{H}_{2} \mathrm{O}\right)$ & 0.06 & 0.06 & 0.22 \\
Salt & 0.28 & 0.28 & 1.04 \\
Codium Bicarbonate & 0.11 & 0.11 & 0.41 \\
Vitamin premix & 0.06 & 0.06 & 0.22 \\
Cilage, normal & 3.1 & 8.83 & 11.43 \\
\hline
\end{tabular}


Table 2. The chemical composition of TMR.

\begin{tabular}{|c|c|}
\hline \multicolumn{2}{|c|}{$\%$ As DM basis } \\
\hline Cp & 19.3 \\
RDP & 12.9 \\
TDN & 75 \\
NFC & 50.9 \\
EE & 3.3 \\
Ca & 0.9 \\
P & 0.6 \\
\hline
\end{tabular}

\section{Requirement balance}

Nutrients that required were completely provided by the diet. The requirement of nutrients and the balance between requirement and supplied are shown in the Table (3).

Nutrition requirements balance calculated according to NRC 2001 NRC, (2001), and the table showed that diet covered the nutrition requirements.

Table 3. Diet nutrient balance.

\begin{tabular}{|c|c|c|c|c|c|}
\hline \multicolumn{6}{|c|}{ Diet nutrient balances } \\
\hline & NEl & MP & Ca & P & K \\
\hline Requirements & (Mcal/day) & (g/day) & (g/day) & (g/day) & $($ g/day $)$ \\
Maintenance & 10.3 & 943 & 21 & 28 & 190 \\
Pregnancy & 0 & 0 & 0 & 0 & 0 \\
Lactation & 31.7 & 2149 & 55 & 41 & 68 \\
Growth & 0 & 0 & 0 & 0 & 0 \\
Total Re- & 42 & 3092 & 76 & 69 & 258 \\
quired & & 3108 & $159^{*}$ & $110^{*}$ & $428^{*}$ \\
Total Sup- & 43 & 16 & 84 & 41 & 170 \\
plied & 1 & 16 \\
Balance & 16 & & & \\
\hline
\end{tabular}

* Note that these mineral supplied values are total absorbable supplied.

$$
\begin{aligned}
& \text { NEI: net energy intake } \\
& \text { MP: metabolizable protein } \\
& \text { Ca: calcium } \\
& \text { P: phosphorus } \\
& \text { K: potassium }
\end{aligned}
$$

\section{Feeds sampling and analysis}

During the entire experiment, representative fresh samples of TMR were collected weekly and stored at $-20 \mathrm{C}$ until analysis. Crude protein (CP), ether extract (EE), crude fiber (CF), neutral detergent fibers (NDF), acid detergent fiber (ADF) and acid detergent lignin (ADL) were determined according to Goering and Van Soest., (1970), Van Soest et al (1991) and AOAC (2006).

\section{Productive performance}

\section{Milk yield and analysis}

Cows were milked three times a day and milk yield was (MY) recorded after each daily milking, during 12 weeks of the experiment. The daily milk yield (DMY) was recorded individually for each cow. Milk samples were collected biweekly and analyzed immediately for fat, protein, lactose content using infrared method by Milk Analyzer (Milko tester Instruments Inc, Bulgaria). Average fat and $\mathrm{CP}$ yields were calculated by multiplying milk yield by fat and CP content of milk on an individual cow basis.

\section{Blood sampling}

Blood samples were collected from Jugular vein. Serum was obtained by centrifugation of blood tubes for $20 \mathrm{~min}, 3000 \mathrm{xg}$ and stored at $-20^{\circ} \mathrm{C}$ until blood metabolites analysis. Concentrations of serum total protein, albumen, urea, glucose, triglycerides, cholesterol, alanine amino transferase (ALT), aspartate amino transferase (AST), urea and alkaline phosphates were determined colorimetric method using commercial kits manufactured by Stanbio Diagnostic Company, Germany.

\section{Statistical analysis \\ Repeated measurement}

Repeated measurements analysis was performed according to the following model:

$y_{i j k}=\mu+\operatorname{trt}_{i}+a_{k}(\text { trt })_{i}+$ time $_{j}+\left(\text { trt }{ }^{*} \text { time }\right)_{i j}+e_{i j k}$ for (milk and blood analysis ).

Where:

$\mathrm{y}_{\mathrm{ijk}}$ milk yield, milk composition or blood analysis.

$\mathrm{k}$ animal of $\mathrm{i}$ trt in $\mathrm{j}$ time

$\mu$ is the overall mean

trti is the effect of $i$ trt $(i=1,2,3,4)$,

ank (trt) i is $k$ animal within $i$ treatment (the first error)

timej is the effect of $\mathrm{j}$ time $(\mathrm{j}=1,2,3,4,5$ and 6 for semen quality and $\mathrm{j}=1,2,3$ and 4 for blood plasma biochemical analysis)

(trt*time)ij is the effect of the interaction between trt and time eijk is the individual error.

2. One way ANOVA ( $T$ independent sample test)

$\mathbf{Y}_{\mathrm{ij}}=\boldsymbol{\mu}+\operatorname{trt}_{\mathrm{i}}+\mathbf{e}_{\mathrm{ij}}$ for (dry matter intake).

One Way ANOVA was according to the following model:

$y_{i j k}=\mu+$ trt $_{i}+$ time $_{j}+\left(\right.$ trt ${ }^{*}$ time $) i_{j}+e_{i j k}$ 
Where:

$\mathrm{Y}_{\mathrm{ijk}}$ dry matter intake

$\mathrm{k}$ animal of $\mathrm{i}$ trt in $\mathrm{j}$ time

$\mu$ is the overall mean

trt $_{i}$ is the effect of $i$ trt $(i=1,2,3,4)$,

time $_{j}$ is the effect of $j$ time $(j=1,2,3,4,5$ and 6 for semen quality and $j=1,2,3$ and 4 for blood plasma biochemical analysis) (trt ${ }^{\star}$ time $)_{\mathrm{ij}}$ is the effect of the interaction between trt and time $e_{i j k}$ is the individual error.

All statistical analysis for the different traits was realized using SAS program (SAS, 2011). Differences among experimental groups were tested by Duncan's Multiple Range test (Duncan, 1955).

\section{RESULTS and DISCUSSIONS}

\section{Effect of probiotic (ZAD) on DMI}

The results show that cows ate diets supplemented with probiotic ZAD consumed more DMI $(15.8 \mathrm{~kg} /$ day) than the control cows that ate diets without supplementation (15.5 kg/day), but the increasing was not significant (Table 4).

Adesogan (2005), explained improvements of feed intake by improvement rumen ability of feed utilization that able to reduce gut fill and increase feed consuming. Similar results were found by Yalçın et al (2011) who found that providing multiparous Holstein cows with yeast culture led to little non-significant increasing in DMI .Gado et al (2009) demonstrated that probiotic ZAD supplementation to dairy cows diets significantly increased dry matter intake from 16.1 to $18.2 \mathrm{~kg} /$ day.

Table 4. The effect of probiotic ZAD on dry matter intake

\begin{tabular}{|c|c|c|c|}
\hline $\begin{array}{c}\text { Time } \\
\text { (week) }\end{array}$ & $\begin{array}{c}\text { Control } \\
\text { (kg/ day) }\end{array}$ & $\begin{array}{c}\text { ZAD } \\
(\mathrm{kg} / \text { day })\end{array}$ & S.E \\
\hline 1 & 14.5 & 14.5 & 0.173 \\
2 & 14.5 & 15.0 & 0.173 \\
3 & 15.0 & 15.5 & 0.173 \\
4 & 15.2 & 16.0 & 0.173 \\
5 & 15.2 & 16.0 & 0.173 \\
6 & 15.5 & 16.0 & 0.173 \\
7 & 16.0 & 16.0 & 0.173 \\
8 & 16.0 & 16.2 & 0.173 \\
9 & 16.0 & 16.2 & 0.173 \\
10 & 16.0 & 16.2 & 0.173 \\
11 & 16.0 & 16.2 & 0.173 \\
12 & 16.0 & 16.2 & 0.173 \\
\hline Overall & 15.5 & 15.8 & 0.16 \\
\hline Control = Group of cows was not supplemented with probiotic \\
ZAD = Group of cows supplemented was probiotic ZAD
\end{tabular}

\section{Effect of probiotic (ZAD) on milk yield and composition}

\section{Milk yield}

At the end of the study average DMY of probiotic ZAD group was significantly more than control group by $2.15 \mathrm{~kg}$. The treatment group produced $41.7 \mathrm{~kg}$ as a daily average, and the control group produced $39.5 \mathrm{~kg}$ (Table 5). The results agreed with (Keneuoe, 2007) who found that treating cows with probiotic (yeast culture), and combination between (probioniacteria $169+$ yeast culture) increased milk yield from $33.9 \mathrm{~kg} / \mathrm{d}$ for control group up to $36.3 \mathrm{~kg} / \mathrm{d}$ and $38.0 \mathrm{~kg} / \mathrm{d}$ for probioniacteria 169 + yeast culture group. Also agreed with Vibhute et al (2011), who supplemented the diets of cows by $20 \mathrm{gm} /$ day/cow probiotic mixture consists of Lactobacillus acidophilus, Saccharomyces cerevisiae, Saccharomyces boulardii and Propionibacterium frendenreichi And noted that milk production increased from $38.1 \mathrm{Kg} /$ day (control) to $43.51 \mathrm{~kg} /$ day (probiotic) after six weeks of treatment. Soliman (2006) reported 23\% increasing in milk production of lactating cows fed peanut hay treated with enzymes and ensiled for 45 day. (Rode et al 1999, Yang et al 1999 and Tricarico et al 2005), explained increased in milk production due to improvement of digestibility.

Beneficial effects of probiotic vary depending on some factors such as age of cow, stage of lactation, type of feeding, amount and duration of probiotic fed, environmental conditions and animal factors, and thus, more studies will be required to determine the optimum conditions that provide the optimal response to probiotic supplementation (Keneuoe, 2007)

Table 5. The effect of probiotic ZAD on milk production

\begin{tabular}{|cccc|}
\hline & $\begin{array}{c}\text { Control } \\
\text { (Liters/ } \\
\text { day) }\end{array}$ & $\begin{array}{c}\text { ZAD } \\
\text { (Liters/ } \\
\text { day) }\end{array}$ & S.E \\
\hline Overall & $39.57 \mathrm{~b}$ & $41.73 \mathrm{a}$ & 0.020803 \\
\hline
\end{tabular}

Control $=$ Group of cows was not supplemented with probiotic ZAD

$Z A D=$ Group of cows supplemented was probiotic ZAD $a, b$ Different litters in the same rows means significant different. 


\section{Milk composition}

\section{Milk fat}

A little non-significant increase in milk fat percentage of the cows that fed probiotic was found in this study (Table 6). Similar results were obtained by Shreedha et al (2016) that studied effect of mix of probiotics on milk fat of to HFxDeoni crossbred cows, and found significant increase as a response to treatment. Beauchemin et al (2003) obtained similar findings too.). No response in fat of milk was observed in cows when supplemented with two specific Enterococcus faecium strains (Nocek and Kautz 2006).

Oetzel et al (2007) suggested that the milk fat of dairy cows increased when cows supplemented with direct fed microbial product containing two strains of Enterococcus faecium and Saccharomyces cerevisiae was due to promotion VFA production.

Table 6. The effect of probiotic ZAD on milk fat percentage

\begin{tabular}{|c|c|c|c|}
\hline & $\begin{array}{c}\text { Control } \\
\%\end{array}$ & $\begin{array}{c}\text { ZAD } \\
\%\end{array}$ & S.E \\
\hline Over all & $3.272 \mathrm{a}$ & $3.28316667 \mathrm{a}$ & 0.01104153 \\
\hline
\end{tabular}

Control = Group of cows was not supplemented with probiotic ZAD

$Z A D=$ Group of cows supplemented was probiotic ZAD

$a, b$ Different litters in the same rows means significant different.

Calculating milk fat yield according to milk fat percentage resulted that the treatment group was higher than control group by 0.7 ( $\mathrm{kg} /$ day), which is an important number in the economic value (Table 7).

Table 7. The effect of probiotic ZAD on milk fat yield

\begin{tabular}{|c|c|c|c|}
\hline & $\begin{array}{c}\text { Control } \\
\text { (kg/ day) }\end{array}$ & $\begin{array}{c}\text { ZAD } \\
\text { (kg/ day) }\end{array}$ & S.E \\
\hline Over all & $1.29 \mathrm{a}$ & $1.36 \mathrm{a}$ & 0.01104153 \\
\hline
\end{tabular}

Control= Group of cows was not supplemented with probiotic ZAD

$Z A D=$ Group of cows supplemented was probiotic $Z A D$

$a, b$ Different litters in the same rows means significant different.

\subsubsection{Milk protein}

In the present study milk protein percent was not influenced positively after treatment of probiotic ZAD it was $3.29 \%$ for two groups control and treatment, and this effect was not significant (Table 8). In agreement with Gado et al (2009) (Keneuoe, 2007) (Higginbotham et al 1994 and Kung et al 1997) who observed that milk protein did not altered after treatment by probiotic. The effect of treatment by probiotic on milk protein percentage was not constant, several studies demonstrated that probiotic had significant positive effect (Titi, 2003), and another studies had not Shreedha, et al (2016) (keneuoe, 2007), but few studies found a negative effect (Harris and Lobo 1988 and Adams et al 1995).

Table 8. The effect of probiotic ZAD on milk protein percentage

\begin{tabular}{|c|c|c|c|}
\hline & $\begin{array}{c}\text { Control } \\
\%\end{array}$ & $\begin{array}{c}\text { ZAD } \\
\%\end{array}$ & S.E \\
\hline Overall & 3.2925 & 3.29333333 & 0.00932819 \\
\hline
\end{tabular}

Control $=$ Group of cows was not supplemented with probiotic ZAD

$Z A D=$ Group of cows supplemented was probiotic $Z A D$

$a, b$ Different litters in the same rows means significant different.

Calculating milk protein yield according to milk fat percentage resulted that the treatment group was higher than control group by 0.07 ( $\mathrm{kg} /$ day), which is an important number in the economic value (Table 9).

Table 9. The effect of probiotic ZAD on milk protein yield

\begin{tabular}{|c|c|c|c|}
\hline & $\begin{array}{c}\text { Control } \\
(\mathrm{kg} / \text { day })\end{array}$ & $\begin{array}{c}\text { ZAD } \\
(\mathrm{kg} / \text { day })\end{array}$ & S.E \\
\hline Overall & 1.3 & 1.37 & 0.00932819 \\
\hline
\end{tabular}

Control = Group of cows was not supplemented with probiotic ZAD

$Z A D=$ Group of cows supplemented was probiotic ZAD

$a, b$ Different litters in the same rows means significant different.

\subsubsection{Milk lactose}

Milk lactose percentage significantly was influenced positively due to treatment by probiotic ZAD in the present study. At the end of experiment the milk lactose percentage was $4.79 \%$ for cows fed diets without supplementation and $4.83 \%$ for cows 
fed diets with supplementation with probiotic ZAD. Similar type of observation was obtained by $\mathrm{Ke}$ neuoe (2007), who found that milk lactose percentage in milk of cows supplemented by mix of probiotic consisted of probioniacteria 169+ yeast culture was $(4.79 \%)$ above than control group (4.63\%) (Table 10).

Table 10. The effect of probiotic ZAD on milk lactose percentage

\begin{tabular}{|c|c|c|c|}
\hline & $\begin{array}{c}\text { Control } \\
\%\end{array}$ & $\begin{array}{c}\text { ZAD } \\
\%\end{array}$ & S.E \\
\hline Overall & $4.79966667 \mathrm{~b}$ & $4.83016667 \mathrm{a}$ & 0.00932819 \\
\hline
\end{tabular}

Control = Group of cows was not supplemented with probiotic ZAD

$Z A D=$ Group of cows supplemented was probiotic ZAD

$a, b$ Different litters in the same rows means significant different.

\subsection{Effect of probiotic (ZAD) on blood parame- ters}

\subsubsection{Blood protein}

Blood protein was affected positively and significantly in this study after treatment by probiotic ZAD. Results showed that total protein was 11.86 $\mathrm{g} / \mathrm{dl}$ for treated cows, and $11.53 \mathrm{~g} / \mathrm{dl}$ for untreated cows. Probiotic ZAD supplementation leaded to improving total protein concentration (Table 11). And these results agreed with Yalcin et al (2011) who found that probiotic improved blood protein concentration insignificantly.

Table 11. The effect of probiotic ZAD on blood protein concentration

\begin{tabular}{|c|c|c|c|}
\hline & $\begin{array}{c}\text { Control } \\
(\mathrm{g} / \mathrm{dl})\end{array}$ & $\begin{array}{c}\mathrm{ZAD} \\
(\mathrm{g} / \mathrm{dl})\end{array}$ & S.E \\
\hline Overall & $11.5255 \mathrm{~b}$ & $11.8588333 \mathrm{a}$ & 0.0024878 \\
\hline
\end{tabular}

Control = Group of cows was not supplemented with probiotic ZAD

$Z A D=$ Group of cows supplemented was probiotic ZAD

$a, b$ Different litters in the same rows means significant different.

\subsubsection{Albumin concentration}

Albumin concentration for control group was $(4.04 \mathrm{~g} / \mathrm{dl})$ higher significantly than treatment group
$(4.02 \mathrm{~g} / \mathrm{dl})$. Results were represented in Table (12). Increasing of albumin concentration in treated cows indicates the good status of liver. Because the liver is mainly responsible for albumin synthesis. Mousa et al (2012)

Table 12. The effect of probiotic ZAD on blood albumin concentration

\begin{tabular}{|c|c|c|c|}
\hline & $\begin{array}{c}\text { Control } \\
(\mathrm{g} / \mathrm{dl})\end{array}$ & $\begin{array}{c}\text { ZAD } \\
(\mathrm{g} / \mathrm{dl})\end{array}$ & S.E \\
\hline Overall & $4.043 \mathrm{a}$ & $4.02 \mathrm{~b}$ & 0.00254877 \\
\hline
\end{tabular}

Control = Group of cows was not supplemented with probiotic ZAD

$Z A D=$ Group of cows supplemented was probiotic ZAD

$a, b$ Different litters in the same rows means significant different

\subsubsection{Urea concentration}

Effect of probiotic ZAD on urea concentration shown in Table (13). and results were urea concentration in treatment group was $34.77(\mathrm{mg} / \mathrm{dl})$ and control group was $33.91(\mathrm{mg} / \mathrm{dl})$, this increase was significant. In agreement with Mohamed et al (2013), but the difference between treatment and control groups was in significant.

Table 13. Effect of probiotic ZAD on blood urea concentration

\begin{tabular}{|c|c|c|}
\hline & $\begin{array}{c}\text { Control } \\
(\mathrm{g} / \mathrm{dl})\end{array}$ & $\begin{array}{c}\text { ZAD } \\
(\mathrm{g} / \mathrm{dl})\end{array}$ \\
\hline Overall & $33.9123333 \mathrm{~b}$ & $34.7706667 \mathrm{a}$ \\
\hline
\end{tabular}

Control $=$ Group of cows was not supplemented with probiotic ZAD

$Z A D=$ Group of cows supplemented was probiotic ZAD

$a, b$ Different litters in the same rows means significant different

\subsubsection{Alkaline phosphates}

Alkaline phosphates increased significantly in treatment group. That control group was $21.105 \mathrm{U} / \mathrm{l}$ and treatment group was $26.92 \mathrm{U} / \mathrm{l}$ (Table 14). Similar results was obtained when Mostafa et al (2014) supplemented dairy cows with bacterial probiotic during pre-partum period. 
Table 14. Effect of probiotic ZAD on Alkaline phosphates concentration

\begin{tabular}{|c|c|c|c|}
\hline & $\begin{array}{c}\text { Control } \\
(\mathrm{U} / \mathrm{l})\end{array}$ & $\begin{array}{c}\text { ZAD } \\
(\mathrm{U} / \mathrm{l})\end{array}$ & S.E \\
\hline Overall & $21.105 \mathrm{~b}$ & $26.9206667 \mathrm{a}$ & 0.0051346 \\
\hline
\end{tabular}

Control = Group of cows was not supplemented with probiotic ZAD

$Z A D=$ Group of cows supplemented was probiotic ZAD

$a, b$ Different litters in the same rows means significant different

\subsubsection{Cholesterol concentration}

Effect of ZAD probiotic on cholesterol concentration is shown in Table (15) significant reduction was found due to treatment. That cholesterol concentration in control cows was $240.98 \mathrm{mg} / \mathrm{dl}$ and in treated cows was $190.13 \mathrm{mg} / \mathrm{dl}$. Mohamed et al (2013) found very similar results after treatment a dairy cows with mix of exogenous fibrolytic enzymes. This reductiom may be explained by improvement in lipid utilization and metabolism (Stein et al 2006).

Table 15. Effect of probiotic ZAD on cholesterol concentration

\begin{tabular}{|c|c|c|c|}
\hline & $\begin{array}{c}\text { Control } \\
(\mathrm{mg} / \mathrm{dl})\end{array}$ & $\begin{array}{c}\text { ZAD } \\
(\mathrm{mg} / \mathrm{dl})\end{array}$ & S.E \\
\hline Overall & $240.980167 \mathrm{a}$ & $190.134 \mathrm{~b}$ & 0.106047 \\
\hline
\end{tabular}

Control = Group of cows was not supplemented with probiotic ZAD

$Z A D=$ Group of cows supplemented was probiotic ZAD

$a, b$ Different litters in the same rows means significant different

\subsubsection{Triglycerides concentration}

In present study triglycerides concentration declined significantly due to treatment of probiotic ZAD. In control cows triglycerides concentration was $27.871(\mathrm{mg} / \mathrm{dl})$ and treated cows was 20.9781 (mg/dl) (Table 16). Triglycerides concentration and cholesterol concentration are the same, reduction of them indicated on improvement in lipid utilization and metabolism (Stein et al 2006).

Table 16. Effect of probiotic ZAD on triglycerides concentration

\begin{tabular}{|c|c|c|c|}
\hline & $\begin{array}{l}\text { Control } \\
\text { (mg/dl) }\end{array}$ & $\begin{array}{l}\text { ZAD } \\
(\mathrm{mg} / \mathrm{dl})\end{array}$ & S.E \\
\hline Overall & $27.871 \mathrm{a}$ & $20.9781667 b$ & 0.3370702 \\
\hline
\end{tabular}

\subsubsection{T3 concentration}

In present study found that T3 concentration increased significantly as a response to treatment by probiotic ZAD. T3 concentration was 117.29 $\mathrm{ng} / \mathrm{dl}$ in treatment group and $62.38 \mathrm{ng} / \mathrm{dl}$ in control group (Table 17). T3 concentration increasing may be due to improvement of metabolism performance of treated cows.

Table 17. Effect of probiotic ZAD on T3 concentration

\begin{tabular}{|c|c|c|c|}
\hline & $\begin{array}{c}\text { Control } \\
(\mathrm{ng} / \mathrm{dl})\end{array}$ & $\begin{array}{c}\text { ZAD } \\
(\mathrm{ng} / \mathrm{dl})\end{array}$ & S.E \\
\hline Overall & $62.385 \mathrm{~b}$ & $117.298833 \mathrm{a}$ & 0.002884 \\
\hline
\end{tabular}

Control $=$ Group of cows was not supplemented with probiotic ZAD

$Z A D=$ Group of cows supplemented was probiotic ZAD $a, b$ Different litters in the same rows means significant different

\subsubsection{ALT concentration}

ALT concentration was higher in treatment group $(52.70 \mathrm{U} / \mathrm{l})$ than control group $(51.16 \mathrm{U} / \mathrm{l})$ in present study (Table 18). Similar results were obtained by Mostafa et al (2014). The activity of ALT and AST increases in dairy cows suffering from liver steatosis. Or in cows with disturbed energy metabolism Mostafa et al (2014)

Table 18. The effect of probiotic ZAD on ALT concentration

\begin{tabular}{|c|c|c|c|}
\hline & $\begin{array}{c}\text { Control } \\
(\mathrm{U} / \mathrm{l})\end{array}$ & $\begin{array}{c}\text { ZAD } \\
(\mathrm{U} / \mathrm{l})\end{array}$ & S.E \\
\hline Overall & $51.1696667 \mathrm{~b}$ & $52.7083333 \mathrm{a}$ & 0.0096449 \\
\hline
\end{tabular}

Control $=$ Group of cows was not supplemented with probiotic ZAD

$Z A D=$ Group of cows supplemented was probiotic ZAD

$a, b$ Different litters in the same rows means significant different

\subsubsection{AST concentration}

AST concentration was higher in treatment group (45.50 U/l) than control group (41.59 U/I) in present study (Table 19). Similar results were obtained by Mostafa et al (2014). 
Table 19. Effect of probiotic ZAD on AST concentration

\begin{tabular}{l|l|l|l|}
\hline & $\begin{array}{l}\text { Control } \\
(\mathrm{U} / \mathrm{l})\end{array}$ & $\begin{array}{l}\text { ZAD } \\
(\mathrm{U} / \mathrm{l})\end{array}$ & S.E \\
\hline Overall & $41.595 \mathrm{~b}$ & $45.5041667 \mathrm{a}$ & 0.4708625 \\
\hline
\end{tabular}
$\begin{aligned} & \text { Control = Group of cows was not supplemented with probiotic } \\
& \text { ZAD }=\text { Group of cows supplemented was probiotic ZAD } \\
& \text { a, b Different litters in the same rows means significant different }\end{aligned}$

\section{REFERENCES}

Adams, A. L. Harris Jr. B. Van Horn H. H. and Wilcox C.J., 1995. Effects of varying forage types on milk production responses to whole cottonseed, tallow and yeast. J. Dairy Sci. 78, 573-581.

Adesogan, A.T., 2005. Improving forage quality and animal performance with fibrolytic enzymes. Florida Rum. Nutr. Symp., pp. 91-109.

A.O.A.C., 2000. Official Methods of Analysis. $17^{\text {th }}$ Ed. AOAC International, Arlington, VA, USA.

Beauchemin, K.A., Rode L.M. and Sewaltm V.J.H., 1995. Fibrolytic enzymes increase fiber digestibility and growth rate of steers fed dry forages. Can. J. Ani. Sci. 75, 641-644.

Duncan, Biometrics., 1955. D.B. Multiple range and multiple F-test, 11, 1-42.

Dutta, TK., Kundu S.S. and Kumar, M., 2009. Potential of direct-fed-microbials on lactation performance in ruminants. A critical. Livestock Research for Rural Development, 21: Article

Dyaa El-Din, A.M., Borhami B. E., El-Shazly K. A. and. Sallam S.M.A., 2013. Effect of dietary supplementation with fibrolytic enzymes on the productive performance of early lactating dairy cows. J. Agri. Sci.; 5(6) 146-155.

Feng, P., Hunt C.W., Pritchard G.T. and Julien W.E., 1996. Effect of enzyme preparations on in situ and in vitro degradation and in vivo digestive characteristics of mature cool-season grass forage in beef steers. J. Anim. Sci. 74, 1349-1357.

Fuller, R. 1989. Probiotics in man and animal. A. Review. J. Applied Bacteriology, 66, 365378.

Gado, H.M., Salem, A.Z.M., Robinson, P.H. and Hassan, M., 2009. Influence of exogenous enzymes on nutrient digestibility, extent of ruminal fermentation as well as milk production and composition in dairy cows. Ani. F. Sci. and Technol, 154(1-2), 36-46.

Gado, H.M and Salem, A.Z.M., 2008. Influence of exogenous enzymes from anaerobic source on growth performance, digestibility, ruminal fermentation and blood metabolites in lambs fed of orange pulp silage in total mixed ration. In: $59^{\text {th }}$ Annual Meeting of the European Association for Animal Production, Vilnius, Lithuania, August 24-27, 228 p.

Goering, H. K. and Van Soest, P.J., 1970. Forage fiber analysis (Apparatus, Reagents, Procedures, and Some Applications). Agriculture Handbook No. 379. Agric. Handbook No. 379 p., ARS. USDA, Washington, DC, USA.

Harris J. B. and Lobo R., 1988. Feeding yeast culture to lactating dairy cows. J. Dairy Sci. 71, 276-288.

Higginbotham, O.E., Collar C.A., Asektube M.S. and Bath, D.L., 1994. Effect of Yeast culture and Aspergillus oryzae extract on milk yield in a commercial dairy herd. J. Dairy Sci. 77, 343348.

Krueger, N.A. and Adesogan, A.T., 2008. Effects of different mixtures of fibrolytic enzymes on digestion and fermentation of bahia-grass hay. Ani. Feed Sci. Technol. 145, 84-89.

Kung. L., Kreck E. M., Tung R.S., Hession A.O., Shepherd A.C., Cohen M.A., Swain H. E. and Leedle J.A.Z., 1997. Effects of a live yeast culture and enzyme on in vitro ruminal fermentation and milk production. J. Dairy Sci. 80, 2045-2051.

Lehloenya, K.V., 2007. Effects on milk yield and components, reproduction and digestion Direct. Fed Microbial supplementation to cattle. Ph.D. Thesis. Oklahoma State University, USA, pp. 1-189.

Mostafa, T.H., Elsayed F.A., Ahmed M.A. and Elkholany M.A., 2014. Effect of using some feed additives (TW-probiotics) in dairy caw rations on production and reproductive performance. Egyptian J. Animal Prod. 51 (1), 111.

Mousa, Kh.M., El-Malky O.M., Komonna O.F. and Rashwan S.E., 2012. Effect of some yeast and minerals on the productive and reproductive performance in ruminants. J. American Sci. 8(2), $291-303$

NRC, 2001 National Research Council. Nutrient Requirements of Dairy Cattle, $7^{\text {th }}$ Ed. National Academy, USA, pp. 60-67.

Oetzel, G.R., Emery, K.M., Kautz W.P. and Nocek, J.E., 2007. Direct-fed microbial supplementation and health and performance of pre- and postpartum dairy cattle: A field trial. J. Dairy Sci. 90, 2058-2068. 
Parker, R.B., 1974. Probiotics, the other half of the antibiotics story. Animal Nutrition and Health 29, 4-8.

Rode, L.M., Yang. W.Z., Beauchemin, K.A., 1999. Fibrolytic enzyme supplements for dairy cows in early lactation. J. Dairy Sci. 82 (10), 2121- 2126

SAS, 2011. Base SAS 9.3 Procedure Guide: Statistical Procedure. Cary, NC, USA.

Shreedhar, J.N., Patil M. and Kumar P., 2016. Effect of Probiotics supplementation on milk yield and milk composition in lactating Holstein Friesian and Deoni Cross Bred cows. J. medical Bioengineering. 5 (1), 19-23

Soliman, M.S., 2006. Utilization of peanut hay in ruminant feeding. Ph.D. Thesis. Alexandria University, Alexandria, Egypt, pp. 1-133.

Stein, D.R. Allen D.T., Perry E.B., Bruner J.C. Gates K.W., Rehberger T.G., Mertz K.J., Jones., 2006. Effects of Feeding Propionibacteria to Dairy Cows on Milk Yield, Milk Components, and Reproduction .J. Dairy Sci. 89,111125.

Titi, H. H., 2003. Evaluation of feeding a fibrolytic enzyme to lactating dairy cows on their lactational performance during early lactation. Asian-Aust. J. Anim. Sci. 16 (5), 677-684.
Tricarico, J.M., Johnston J.D., Dawson K.A., Hanson K.C., McLeod K.R. and Harmon D.L., 2005. The effects of an Aspergillus oryzae extract containing alpha-amylase activity on ruminal fermentation and milk production in lactating Holstein cows. Anim. Sci. 81, 365374.

Van soest, P. J., Robertson, .J.B. and Lewis B. A., 1991. Methods for dietary fiber, neutral detergent fiber, and nonstarch polysaccharides in relation to animal nutrition .J. Dairy Sci., 74 (10), 3583-3597

Vibhute, V.M., Shelke R.R., Chavan S.D. and Nage S.P., 2011. Effect of Probiotics supplementation on the performance of lactating crossbred cows. Vet. World, 4 (12), 557-561.

Yalçın S., Can. P., Gürdal. A., Bağcı. C and Eltan. Ö., 2011. The nutritive value of live yeast culture (Saccharomyces cerevisiae) and its effect on milk yield, milk composition and some blood parameters of dairy cows. Asian-Aust. J. Anim. Sci. 24 (10), 1377- 1385

Yang, W. Z., Beauchemin K. A. and Rode L. M., 1999. Effects of an Enzyme Feed Additive on Extent of Digestion 1 and Milk Production of Lactating Dairy Cows. J. Dairy Sci., 82, 391403. 



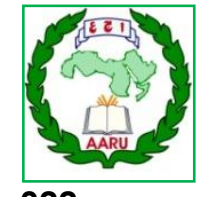

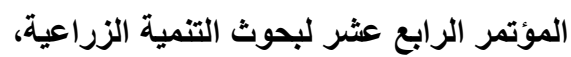

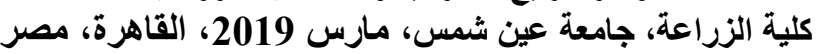

مجلد(27)، عدد (1)، عدد خاص مارس، مارس 322-313، 2019

Website: http://strategy-plan.asu.edu.eg/AUJASCI/

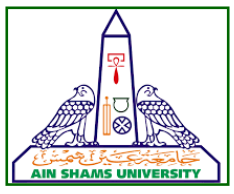

تأثير البرويايوتيك على اداء المجترات

[28]

\author{
عبدالرحمن فتحي البريري - هاني محمود جادو - حمدي محمد خطاب

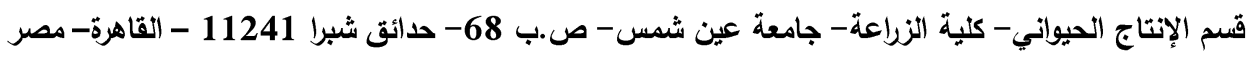

"Corresponding author: abdelrahman.fa@gmail.com

Received 14 October, 2018, $\quad$ Accepted 24 October, 2018

المعاملة بالزاد لكن الزيادة كانت غير معنوية. وظهر التادير

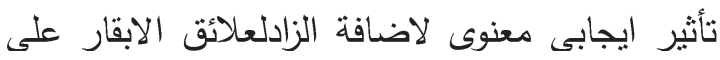

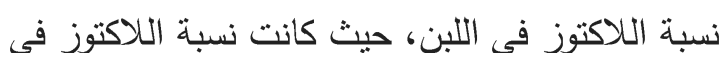
لبن الابقار الكونترول 4.79\% و 4.83 \%

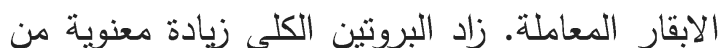
11.52 بالنسبة لمجموعة الكونترول و11.85 بالنسبة النية

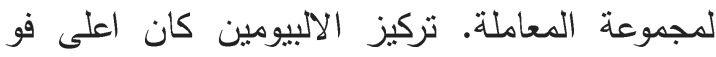
مجموعة المعاملة وبشكل معنوى. وكانت نتيجة المعاملة بالزاد على تركيز اليوريا في

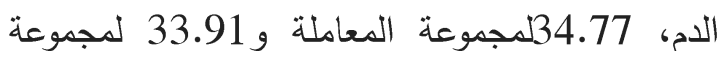
الكونترول، والزيادة كانت معنوية. الكالاين فوسفاتيز

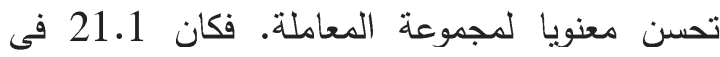
مجموعة الكونتول و 26.92 فى مجموعة المعاملة. انخفض الكوليسترول معنويا بسبب المعاملة بالزاد

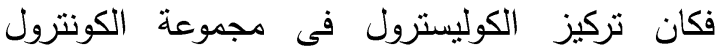

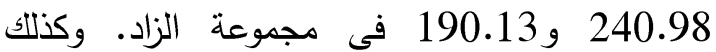

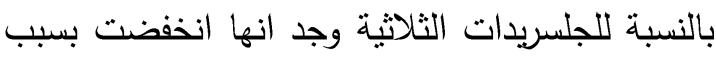
المعاملة بازاد فكانت 27.871 فى مجموعة الكونترول

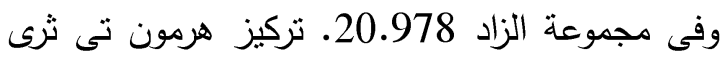
زاد زيادة معنوية نتيجة للمعاملة بالزاد فكان تركيز الهرمون 117.29 في مجموعة المعاملة و 162.28 في تئل

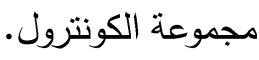

الكثمات الدالة: البروبايوتيك، المجترات، زاد، الإتتاج،

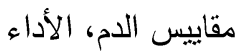

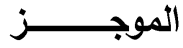

أجريت التجربة فى مزرعة الأمل بالقاهرة- مصر

وتمت على عدد 200 بقرة قسمت إلى مجموعتين.

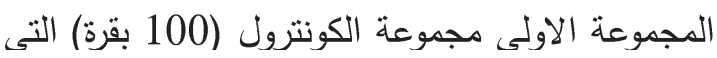

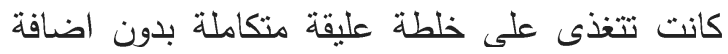

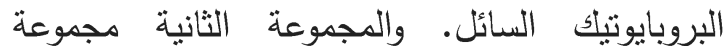

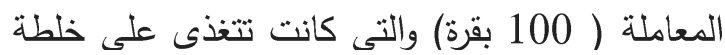

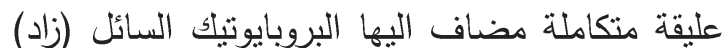

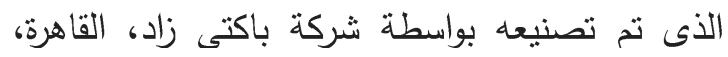

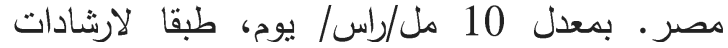

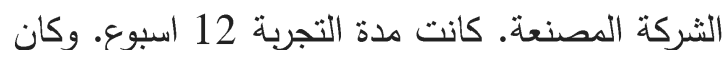
يتم اضافة الزاد وخلطة فى وقت التغذية مرة واحدة يوميا. وتمت تربية كلتا المجموعتين فى عنابر مظللة تربية حرة.

والهدف من التجربة هو دراسة تأثثر استخدام البروبيوتيك على الاداء الانتاجى والفسيولوجى للابقار

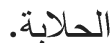
وكانت نتائج التجربة كالتالى عند دراسة تأثير الزاد على محصول التئ اللبن كانت النتيجة بزيادة محصول اللبن زيادة معنوية من 39.5 كجم/ يوم بالنسبة لمجموعة الكونترول الى لئل 41.37

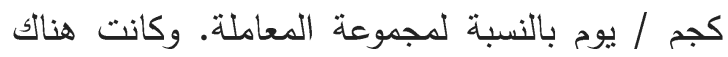

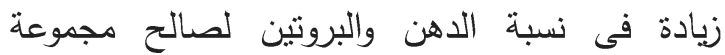

\footnotetext{
تحكيم: ا.د سلوي محمود حمدي

ا.د جمال عاشور حسن
} 